Проф. др Маја Ђукановић

Проф. др Весна Половина

Универзитет у Београду

$821.163 .41^{\prime} 255.2=133.1$

Филолошки факултет

$821.163 .41^{\prime} 255.2=163.6$

polovinav@fil.bg.ac.rs

$821.163 .41^{\prime} 255.2=111$

https://doi.org/10.18485/ai_andric.2018.ch14

\title{
КУЛТУРНО-СПЕЦИФИЧНА ЛЕКСИКА У ПРЕВОДУ ИВА АНДРИЋА НА СЛОВЕНАЧКИ, ФРАНЦУСКИ И ЕНГЛЕСКИ ЈЕЗИК
}

Тематика и садржај књижевног опуса Ива Андрића обилују лексиком којом писац дочарава климу, епохе, обичаје и филозофију живота људи који су у одређеном периоду насељавали простор у коме смешта догађаје својих романа и приповедака. У раду су представљени резултати анализе лексике на грађи из приповетке „Аникина времена“ и превода на француски, енглески и словеначки језик, а којом писац означава специфична обележја материјалне и духовне културе у временима и местима које описује.

Кључне речи: Иво Андрић, културно-специфична лексика, превод, енглески, француски, словеначки.

I. У литератури о превођењу често се експлицитно или имплицитно пажња фокусира на онај тип лексике која из разних разлога представља специфичне елементе културе језика са кога се преводи, а које је тешко исказати на другом језику тако да та специфичност опстане. Овакав тип лексике се означава терминима безеквивалентна лексика, егзотизми, локализми, дијалектизми, културне реалије и сл. Према Влахову и Флорину (1981: 47-52), културне реалије су речи карак- 
теристичне за живот једног народа (обичаје, културу, друштвени и историјски развој). Пошто су такве речи носиоци националног и историјског колорита, оне по правилу немају еквивалената у другим језицима. О превођењу овакве лексике писало се доста и код нас и у свету, а овај рад се у великој мери ослања, поготово када су у питању одабир културно-специфичне лексике и преводи на словеначки и француски, на претходно објављени рад једне од ауторки (Ђукановић, М., 1992), те представља његово проширење и допуну.

Познато је у теоријама превођења које почивају на структуралистичком приступу језику да лексика уопште, а не ради се само о културно-специфичној, 'безеквивалентној', у сваком језику има своја специфична системска обележја. Тако, рецимо, Nida (1982), показује на примерима попут енглеског the motor runs и француског le moteur marche, да се исто значење, у сасвим обичној, свакодневној и стилски необележеној лексици, преноси лексемама које ван контекста „мотора“"не би биле еквивалентни преводи. У природи је језика да лексеме могу да истичу једну или другу од својих компоненти значења, не само у зависности од контекста, већ и од система лексичких поља датог језика. Наводи пример лексичког поља: repentance, remorse, conversion у коме су присутне, у низу, следеће значењске компоненте: прво „лоше понашање“, затим „туга због тога“, и на крају, „промена понашања“. Његов пример је грчки metanoē̄ које пре значи „to change one's ways“ него „to change one's mind“. У другим језицима нагласак је на "sorrow for the sin“ или „to leave the sin behind“, или „to change in the heart“ (Nida 1982: 67). Дакле, ако би неки минимални захтев за преводиоца био да две речи имају опште заједничко значење, то не значи да нека додатна, специфична значења не треба пренети на 
Културно-специфична лексика у преводу Ива Андрића... 243

други језик, поготово ако се испостави да су и та значења била намеравана (Nida 1980: 78). Пошто се у овом раду бавимо специфичном, често опционом лексиком - највише турцизмима у једном тексту И. Андрића и њиховим преводима на три страна језика, претпоставили смо да би се нешто од тог специфичног „колорита“ требало наћи и у преводима. Одсуство такве обојености у преводу, тзв. одомаћивањем стране лексике (нпр. чакшире - pantalon, trousers), свођењем културних специфичности изворног текста на језичко-културне вредности текста превода, чини превод транспарентним, лакшим за разумевање (Munday 2001: 146). Задржавање, пак, специфичности из оригинала (касаба - kasaba, или чакшире - Turkish trousers) може приближити превод оригиналу, али увек постоји опасност да се таква решења у преводу доживе као претерано истицање „егзотичности“.

То се не може проценити само на основу појединачних израза, синтагматског контекста, већ је потребно имати на уму и шире целине, текст који може на специфичан начин даље умрежавати лексичка значења. Појединачне речи не морају бити важне, али у склопу целине постају. Добро је задржати локални говор и језичке обрасце, али само у одређеној мери (Munday 2001: 150).

Текст чијим се превођењем бавимо јесте приповетка „Аникина времена“ Иве Андрића. Навешћемо неке опаске о књижевним поступцима Андрића за које сматрамо да могу бити релевантне и за нашу тему. Говорећи о целокупном делу његовом Зоран Милутиновић (2009) у уводу у збирку приповедака на енглеском језику каже, између осталог, да се Андрићеве приповетке фокусирају не толико на ликове колико на место где се дешавају (Вишеград, Травник, Истанбул) 
(стр. хіх), те да, рецимо, касаба постаје нека врста лика колектива. И заиста, кад погледамо примере језичког контекста ове лексеме у приповеци „Аникина времена“: „И све што је у то време узбуђивало касабу и свет у њој“, „Касаба није ӣрестиајала gа їовори о Крнојелчевој кћери која се одједном задевојчила“, „Аника је успела

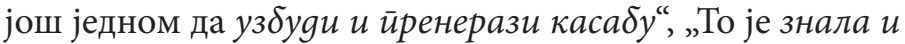
осећала и цела касаба“, „Касаба, која се била пореметила и подлегла привремено, може оиети ga guше својим сииарим, ирравилним дахом, gа мирно сйава, gа слобоgно ілеgа“, - секундарно значење назива места као живог колектива је често у тексту. Оно одређује свима, па и људским ликовима образац понашања, а када се тај образац поремети, последице по појединце могу бити добре или лоше, али касаба враћа све у равнотежу. По Милутиновићу, Андрић тежи да пружи „the fabric of real life" (xxxviii). То, рецимо, чини у многим приповеткама враћајући се у прошлост, те у „Аникинима временима“, од приче о поп Вујадину иде ка даљој прошлости са причом о Аники, и још даље, ка причи о Тијани (Милутиновић, xxxiv). Мада овај аутор на једном месту каже, у вези са разграничењем традиционалног и модерног код Андрића, "in Andrićs works that which is specifically modern is achieved by a means which cannot be detected at the language level" (xхіх), сматрамо да језичка анализа може ипак бар део те књижевне слојевитости да расветли, као што књижевна критика, сагледавајући дела из другог аспекта и као целине, може помоћи у разматрању проблема у преводу таквог дела на други језик.

II. Као илустративан пример лексике која је културно специфична, а са којом се сусрећу преводиоци дела Иве Андрића, осврнућемо се посебно, као што смо 
Културно-специфична лексика у преводу Ива Андрића... 245

већ напоменули у уводу, на турцизме и колорит који они собом носе. Сматрамо да је таква лексика, између осталог, један од начина на који се тексту даје регионална, просторна и временска димензија. Сходно подели коју даје А. Шкаљић у своме речнику турцизама (Шкаљић 1965) у грађу нису ушли они турцизми који су се потпуно одомаћили у српском језику и за које уошпте нема замене (боја, џеп, кутија, шећер и сл.). Међутим, сам текст приповетке навео нас је да некада занемаримо ову границу, па се бавимо и неким турцизмима који су одомаћени (капија - на пример), а за које се понекад може употребити и домаћа реч, пошто се те лексеме јављају у одређеном лексичком пољу које обрађујемо. Уосталом, треба имати на уму да је граница између одомаћених позајмљеница и туђица релативно субјективна и временски променљива категорија.

Текст приповетке „Аникина времена“ и његови преводи на словеначки, француски и енглески послужили су као пример на коме се може истражити део лексике која представља ове културолошко-језичке проблеме. 3бог веће сродности словеначког језика српском, па и географске и историјске веће блискости, што се огледа и у томе да је словеначки попримио неке турцизме као и српски: džezva, ajvar, kajmak и сл., претпоставили смо да hе се на том језику неки изрази успешније транспоновати него на француском и енглеском, с обзиром да је тим културама поднебље из Андрићевог дела удаљеније. Примери су узети из превода на словеначки Јанка Модера, на француски Ан Јелен, енглески Дренке Вилен ${ }^{1}$, а оригинал је коришћен у издању Матице српске и Српске књижевне задруге (Нови Сад-Београд, 1971).

1 I. Andrić, 2009. The slave girl : and other stories about women; Gorup, R. (ed.), - број стране се у случају енглеског превода из 1962 , односе на прештампани текст у издању из 2009. године. 
Најдетаљнији преглед и поделу културно-специфичних реалија дали су С. Влахов и С. Флорин (1981). Ослањајући се на њихову, ексцерпирана грађа обухвата пре свега етнографске реалије, које се односе на:

свакодневни живой: одећу, покућство, јело и пиће, делове куће и окућнице, ктетике

pag: занате и врсте послова; објекте; мере и новаи; gрушитвено-йолитиччке реалије административно-територијалну организацију; релиілју; црквена хијерархија, празници (Према Флорин, 1981: 47-52)

Прва група културно-специфичних реалија, из области свакодневног живота, обухвата одећу у ширем смислу. Ту спадају делови ношње (у загради је означен број стране): на јечерми (190) - na oplečniku (98), sur son gilet (51), in silk garment (403); маше шамијама (163) - z naglavnimi rutami (72), de foulards (17), (waving ...) skirts (369); у gубоком иеӣy og чакщира (187) - v globokem hlačnem žepu (96), la poche profonde de son pantalon (48), deep in the pockets of his trousers (400). Сва три турцизма: јечерма, шамије, чакшире, преведена су углавном неутрално. Ипак, с обзиром да се лексема јечерма јавља два пута, и то у кад се приказују сцене убијених јунакиња - Тијане и Анике, можемо претпоставити да није случајно што је исти део одеће, као украшенија и отменија варијанта „јелека“, наведен као оскрнављени део, те је рецимо у енглеском преводу такође могао да остане „silk garment/vest“ на оба места у тексту, а не само "vest". (A great black wound could be seen in her blue silk garment (403), и her vest and shirt were pierced between the breasts (438)). Зашто су шамије постале skirts у енглеском преводу нејасно је.

Од накита се, на пример, помињу „gукайи с врата

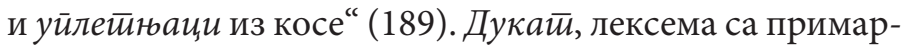


Културно-специфична лексика у преводу Ива Андрића... 247

ним значењем „златног новца“, у нашој народној ношњи и поднебљу користи се и као накит, а за словеначког, француског и енглеског читаоца представља само златни новац, најчешће венецијански. Међутим, пошто реченични контекст гласи: „губећи.. дукате с врата», а тај контекст је, наравно, пренет у сва три превода, јасно је да је реч о украсу. За разлику од дуката, уйлейғьаци, које савремени српски читалац може да разуме само захваљујући творбеној основи лексеме али је свакако више не користи, преведени су различито. Преводилац на француски одлучио се за први део објашњења - украс (ornement), преводилац на словеначки за други део објашњења - trak, jep, уплетњаци и јесу украсне траке, док је енглески преводилац превео једноставно ca - pins, (ducats fell from her neck and pins from her hair, str. 403), иако на енглеском постоји добар еквивалент (hair ribbons).

Једна подгрупа лексема блиска одећи обухватила би разне врсте торби. Тако за зембиљ (185), налазимо следеће преводне еквиваленте: cekar (94), un sac (46), basket (397); за „пун фишек лимунова“ (202): polno torbo limon (111), un sac de citrons (68), the bagful of lemons (419); за јанцик и йорбу (219): usnjeno in platneno torbo (219), un sac de cuir et une musette (87), a bag (437). Француско un sac општи је назив за све врсте торби. У трећем примеру преводиоци су прибегли истом решењу, а најтеже је, изгледа, било превести реч фишек. У енглеском је искоришћена могућност морфолошке деривације - исказивања количине уз помоћ садрживача: bagful. Највеће „поједностављење“ употребом хиперонима остварио је преводилац на енглески, који је координирану синтагму за трећи пример од два кохипонима (јанџик и торбу) у српском, скратио у „bag“, лексему са општим значењем. 
Из групе реалија коју сачињава йокућсйво издвојићемо делове намештаја и делове куће. Делови намештаја типични за турске куће преведени су различито: седи на минgерлуку (197): na divanu (106), sur le canape (61), on the low minderluk (413). Турцизам миндерлук преведен је неутрално, осим у случају енглеског превода где је задржан турски назив уз додатни атрибут „низак“, али се у књизи енглеског превода, при крају, налази глосар који минgерлук објашњава као „а type of sofa". За разлику од те лексеме, занимљив је превод израза: на gушеклуку (219) - na omarici za blazine (128), sur le matelas (88), on the mattres (438). Могуће je да је душеклук завео преводиоце на француски и енглески који су помислили да је реч о душеку (matelas, matress), мада, с обзиром на драматичност сцене (тела мртве Анике у собици која се описује), могуће је и да неки од преводиоца нису желели да додатно оптерећују сцену „непотребним“ детаљима, или описним синтагмама (bed linen cupboard).

У ову групу реалија сврстани су и делови куће: gиванана (204) - mostovž (113), le parloir (70), on the porch (421). Значење словеначког термина mostovž у великој мери се поклапа с дивананом у просторном смислу, међутим намене су им различите: мостовж је врста ходника и не служи за разговор. Le parloir, као и енглеско porch, пак, сасвим одговара значењу овог турцизма. Пред преводиоце се поставља и проблем прављења разлике између кайије и врайа. У једном случају преводилац на француски је реченицу где се помињу „сва дућанска врата, све кућне капије“ (217) једноставно испустио, док је у другом сличном примеру („дрвена брава на капији... врата на кући“ (218)) обе речи превео неутралним la porte. Преводилац на словеначки имао је боље решење - капију преводи синтагмом vežna vrata. 
Културно-специфична лексика у преводу Ива Андрића... 249

Veža је према Речнику словеначког књижевног језика, пролазни простор иза улазних врата. Преводилац на енглески није у овом случају имао недоумица, капију је преводио са gate, а врата ca door: "the shop door, the house gates" (437).

Реалије које се односе на јело $и$ üuће $y$ ексцерпираним примерима углавном се своде на хлеб и ракију. Сомун (округли пекарски хлеб - према Речнику турцизама) и хлеб грошњак (хлеб од гроша - Речник Матице српске) на словеначки су преведени боље него на француски и енглески: на сомунима (210) - v hlebec kruha (119-120), sur les pains blancs (77), the bread loaves (429), а пуне и беле хлебове ірошюаке (215) - shajane bele pogrošene hlebčke (124), les pains blancs et ronds (84), full white loaves (434). Словеначки hlebec kruha означава округао хлеб, што сомун и јесте, док pogrošen значи јефтин. Француски преводилац задржао се на уопштеном le pain, као и енглески на bread loaves.

Ракија је од француског преводиоца захтевала чак и фусноту, енглески преводилац је преузео исти термин: rakiya, док се словеначки преводилац одлучио за еквивалент žganje. Кад је реч о шербетиy он је словеначком преводиоцу најсличнији медовини, па га тако и преводи: medica. Грешка је, међутим, у томе што је medica алкохолно пиће, а шербет „добро заслађена вода која се пије ради освјежења“ (Речник турцизама). Преводилац на енглески је ту реч изоставила, односно синтагму: „само продавци слаткиша и шербета“ превела је са: candy and food vendors (423).

Са јелом и пићем у вези је и посуђе: исйијао ӣoлић наgушак (192) - zvračal kozarce na dušek (101), vidait la bouteille (55), emptying one glass of rakiya after another (406). Полић, који рибар „испија надушак“ у кафани, захвата „пола литре (за вино) или пола децилитра за ра- 
кију“ (Речник Матице српске). Преводилац на словеначки одлучио се за чашу, док је преводилац на француски сматрао да рибар празни читаву флашу, а енглески да је пио чашу за чашом пиће. Чини се да је на преводиоце утицао глаголски вид: „испијао“ и то што је за рибара у претходним редовима речено да је „пијаница“, иако се сцена одвија у дућану, у коме се рибар кратко задржао.

Уз ракију иде и мезетлук: мезетиили рибу (192) prigrizovali ribe (101), mangaient du poisson (55), snacking on fish (406). За глагол мезетиитии у француском није нађен одговарајући еквивалент, док су решења на словеначком и на енглеском, захваљујући творбеним потенцијалима тих језика, свакако боља.

Под појам окућница сврставају се: авлија, појата, плот, тараба. Авлија је преведена неутрално, а кад је реч о $\bar{u} о ј а \bar{u} и$ словеначки превод senik и енглески hayloft адекватнији su од француског les dépendances. Словеначки преводилац је $\bar{u} л о \bar{u}$ и $\overline{\text { } а р а \delta у ~ п р е в е о ~ т е р м и н о м ~}$ који означава ограду од коља, енглески је имао на располагању одговарајући: fence, док је преводилац на француски искористио постојање сличних термина la barriere - la palissade.

Од кйейика се као интересантни за превођење издвајају Османлија и Влахиња: двојица угојених Ocманлија (208) - dva rejena Turka (118), deux Osmanlis (75), two well-fed Turks (426); Влахиюь са Мејдана (222), Vlahinja s trga (130), la Serbe du Meidan (91), the Christian woman from the Meidan (441). Кад је реч о Влахињи она је на француски преведена la Serbe, што и јесте. Власи су на подручју Босне и Херцеговине опозит Муслиманима, док на словеначком Vlah између осталог означава православно становништво, пре свега у Белој Крајини. За разлику од словеначког и француског превода на енглеском се истиче само опозиција према исламској религији. 
Културно-специфична лексика у преводу Ива Андрића... 251

Турцизми којима су означени уобичајени занати нису представљали већи проблем:

йуфеіиијске породице (173) - puškarske rodovine (83), d'un famille d'armiers (31), family of gunsmiths (382); иелебиија уз стоку (179), živinski mešetar (88), conducteur de betail (38), a herdsman (391).

Проблем за преводиоце представљао је кафеција (kavaiji; les aubergistes; inn-keeper). Словеначко kavar није ушло у фонд Речника словеначког књижевног језика. Јанко Јуранчич у свом српскохрватско-словеначком речнику даје предлог kavarnar (према Речнику словеначког књижевног језика kavarnar је власник, управник кафане), међутим, како је из контекста јасно да је овде у питању „онај који куха кафе“ (Речник турцизама), сасвим је оправдано увођење неологизма. Француско aubergiste, као ни словеначко kavarnar није адекватан превод јер означава власника кафане, док енглески превод не подразумева „власништво“, већ вођење посла.

Органи реда - зайиије и жанgари, преведени су на словеначки и француски истим терминима: orožniki $(77,87)$, les gendarmes $(24,36)$. Интересантно је да позајмљеница из немачког фрајкор (Freikorps) није ушла у словеначки и француски: жандара и сувишних фрајкора (164) - orožnikov in nepotrebnih prostovoljnih oddelkov (74), de gendarmes et de corps-francs (19); енглески превод je: full of gendarmes, gendarmes (371-372), (413), док се на другим местима за заййије, зависно да ли је та лексема у једнини или множини, користе и термини: police force (407), policeman (410), police (416).

Турски називи за органе управе на словеначки су преведени генерализовањем, док се преводилац на француски послужио увођењем фусноте: вишеградском кајмакаму (193) - višegrajski okrajni glavar 
(102), kaimekam de Vichegrad (chef de police turc) (56), kajmakam, the Mayor of Visegrad (407), the mayor or kajmakam (408); Мула Ибрахим Кука... чувеног муйевеruje (166) - Mula Ibrahim Kuka... znamenitega upravnika (75), Moula Ibrahim Kouka... un moutevelia (21), (chez les Turcs musulmans, administrateur de fondations pieuses), Mullah Ibrahim Kuka ... mutavelija Mullah Mehmed (373) - у енглеском глосару је објашњен појам муле: Ottoman scholar, али не и мутавелије.

Занимљиво је да су доста тешко преведени термини койач, момак и їазgа. Код койача (159) - pri delavcih (69), chez les cultivateurs (12), the men working in the field (364); момии су им чували коюе (159), hlapci so pazili (69), les domestiques (13), grooms...horses (364); момка Радивоја (160) - sluga Radivoje (70), son serviteur (14), servant (360). Словеначко delavec је општи појам, еквивалент српском раднику, док је француско cultivateur у ствари земљорадник, а у енглеском елемент значења имплицитног код српског „копач“ - надокнађен је кроз предлошку синтагму „у пољу“. Ни појам їaзga, то јест семантички елементи које ова реч у себи садржи („сопственик, власник радње, послодавац, имућан човек“ - према Речнику Матице српске) није било лако превести. Преводилац на француски се и овде одлучио за фусноту: „Gazda: riche proprietaire, maître.“ На енглеском master и словеначком gospodar у великој мери покривају исто семантичко поље.

Кад је реч о занатским објектима, најчешће се срећу појмови $х а н$ и механа. И у овом случају изгубило се на богатству у преводима, јер су оба појма преведена на словеначки као крчма, на француски l'auberge, док на енглеском налазимо варијанте: han (383), roadside inn (394). У два превода, словеначком и француском, губи се значење „зграда која служи за свратиште и пре- 
Културно-специфична лексика у преводу Ива Андрића... 253

ноћиште путника“, док је у енглеском задржан тај део значења. Други примери, као на пример екмешчинииз, преведени су без проблема (pekarija, la boulangerie, bakery).

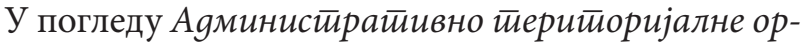
іанизације примећујемо да преводилац на словеначки и варош и касабу и (у једном случају) чаршију преводи као mesto, док преводилац на француски употребљава различите изразе: bourgade, cité, ville, marche. Мада ниједан од ових израза не означава турски тип насеља, барем је јасно да је у питању мањи град. Енглески преводилац доследно употребљава исту реч kasaba и то курзивом истакнуту, а у глосару је дефинише као: Provincial town in Ottoman Bosnia. Доста добра решења нађена су у преводу на француски за чаршију: le marché, le bazar. У енглеском преводу је čaršija објашњена у глоcapy: Business district or downtown. Исти принцип је енглески преводилац применио за појам kadiluk, а преводилац на француски уводи фусноту и реч ставља под наводнике, па у даљем тексту тај појам употребљава као уобичајен.

Занимљива су решења микротопонима Жуйа

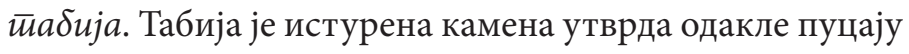
топови, бастион (према Речнику турцизама). Примери

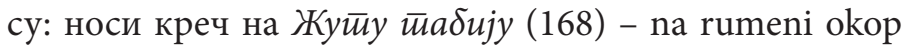
(77), Jouta Tabiya (24), Žuta Tabija (375). У преводу на словеначки овај микротопоним је преведен, на француски транскрибован, на енглеском преузет у оригиналном облику (Žuta tabija). Словеначки превод донекле одсликава изглед насеља, док транскрибовани или исти назив страном читаоцу не говори ништа.

Кад су у питању мере и новач, ексцерпирана грађа обухвата само два примера: gве оке шећера (185) - dve oki cukra (94), deux livres de sucre (45), two half- 
pack of sugar (397); ни йара не бали (188) - tudi pare ni premalo (97), pas un centime ne manque (50), not a penny missing (401). Мада је ока 1250-1280 грама, а француска мера la livre 380-550 грама, овај функционални превод је срећно решење, јер су у оба случаја у питању старе народне мере. У енглеском преводу уопштено је у два „полу-паковања“ - колико год она тежила. Кад је реч о пари, centime је у француском стоти део франка и у овом случају би више одговарао општији термин le sou.

Реалије везане за релиіију могу се поделити у неколико група. У оквиру црквене хијерархије налазе се термини: прота-протиница, поп-попадија, свештеник, владика и ђакон. Примери су: зgрава и речийа свешиеника... йой-вујаgина (156) - duhovnika...popa (66), le pope... le pope (8) - и поред термина le prétre, преводилац на француски у овом примеру у истој реченици два пута употребљава реч le pope. За $\bar{u} р о \bar{u} о-\bar{u} р о \bar{u} и н и-$ u,a (191) у преводима налазимо: prota-protovka (100), le cure-la femme de cure (53). У енглеском доследно се користи priest, Father Vujadin (360) за поп + властито име, parish priest (404), Dobrun priest (402), the priest's wife (481). У словеначком се види да је да је реч о православном свештенику, док се у друга два језика тај елемент значења губи. За реч влаgика преводилац на француски даје фусноту с објашњењем, док енглески преводилац само даје еквивалент: bishop. Ђакон је на сва три језика преведен одговарајућом лексемом.

Верски празници преведени су католичким еквивалентима: на ђурђевgански йеферич (181) - na jurjevsko veselico (90), au pique-nique de la Saint-Georges (40), St George's feast (393); до илинденскоі вашара (183) - do sejma na iljevo (92), jusque'a la foire de la SaintElie (44), The feast of St Elias (395); о Госйојини (197) - о velikem šmarnu (106), pour l'Assomption (61), the day of 
Културно-специфична лексика у преводу Ива Андрића... 255

Our Lady (412); уочи Мале Госйојине (200) - о malem šmarnu (109), la veille de la Nativite de la Vierge (65), the day of Our Lady (417).

III. Напред приказана грађа, ексцерпирана из Андрићеве приповетке „Аникина времена“ и њених превода на три језика, може се, са преводилачког становишта, посматрати на основу више критеријума. У настојању да уопштимо резултате до којих смо дошли, ослонићемо се на типове преводилачких поступака за културне реалије које даје Флорин (1981): І. Увођење неологизама (калк, полукалк, адаптација и увођење семантичког неологизма); II. Приближни превод (генерализовање, употреба функционалног еквивалента и описни превод); III. Контекстуални превод (као опозит „речничком“ преводу)

У наведеним преводима турцизми су често преведени неутрално, при чему се изгубила боја коју они имају у српском језику, поготово тамо где постоје њихови неутрални еквиваленти (на пример екмешчиница: пекара; шамија: марама и сл.). Неки турцизми су током времена полако нестајали, те су савременом читаоцу непознати (заптија, џелебџија, табија и сл.), или само делимично познати, наравно у зависности од дијалекатског, географског или религијског залеђа. Њихова, пак, функција у тексту приповетке свакако има везе са наведеним историјским слојевима у наративном поступку аутора, те стога турцизми представљају знакове прошлих времена, и у том смислу захтевају посебну пажњу.

Неки од турцизама и реалија се објашњавају у напоменама а за неке је нађен еквивалент. Преводилац на словеначки ни у једном случају није посегнуо за првим, помоћним средством. Насупрот овоме, француски 
превод је у приличној мери оптерећен објашњењима и фуснотама, од којих су нека непотребна. На пример, преводилац уводи у француски реч le gazda, објашњава је у напомени, иако постоји сасвим одговарајуће le maître, a не може бити у питању жеља за одржавањем „локалне боје“, јер егзотизама и турцизама има довољно на другим местима у приповеци. За француски превод се може рећи да је по броју напомена прилично информативан, али информативност која одвлачи пажњу читаоца са главног тока приче није увек оправдана. Енглески превод има доста преузетих турцизама које у тексту обавезно штампа курзивом, а садржи и глосар на крају књиге.

Од анализиране лексике, и у француском и енглеском преводу ови неологизми, речи уведене у облику који је исти као у оригиналу, најчешће могу да се сврстају у групу административно-територијалне лексике. Енглески превод употребљава наша латинична слова (kajmakam, Žuta tabija, нпр.), док француски такве турцизме прилагођава својој ортографији.

У највећем броју случајева дат је приближни превод, без обзира да ли се ради о турцизмима или српским изразима. Генерализовање (чакшире - hlače/ pantalons/trousers), употреба функционалног еквивалента (теферич - veselice, pique-nique, feast), описни превод (душеклук - omarica za blazine) понекад, истина, могу утицати на губљење локалне боје, али се то може надокнадити на другим местима. У вези са преношењем националног и историјског колорита овакав став заступа и Ј. Леви (1982: 110-111) наводећи да се при превођењу не могу сачувати сви елементи оригинала, него код читаоца ваља „изазвати утисак, илузију историјске и националне средине“. Вероватно се тиме могу оправдати и неки други случајеви непостојања 
Културно-специфична лексика у преводу Ива Андрића... 257

еквиваленције у преводу. Тако се може, уопштавањем, коришћењем надређеног појма, рећи да је основно значење пренесено, али се онда поставља питање до које се мере може проширити појам „основног значења“, односно да ли се исто објашњење може дати и за свођење синтагми попут „врата и капије“ само на један термин у француском, или „јанџак и торба“ на енглеском, или слободно варирање „слаткиша и шербета“ на „слаткише и храну“ у енглеском.

Неки од превода се можда могу окарактерисати и као грешке: „душеклук“ је део намештаја у који се смештају душеци и постељина, а у преводу су дати као „душек“. Шамије су у енглеском преводу постале „сукње“, а уплетњаци - „укоснице“. Једино могуће објашњење у неким од тих случајева је жеља да се избегне описни израз који би можда пореметио ритам или звук речи и реченице: рецимо, ducats fell from her neck and pins from her hair, има добар синтаксички паралелизам у коме оба субјекта почињу плозивом, па је могуће да је преводиоцу напросто боље звучало да стави „укоснице“ него траке.

С друге стране, може се рећи да контекстуални превод одлично функционише нарочито када су у питању сасвим једноставни, свакодневни појмови. Тако у енглеском преводу „копача“ налазимо уопштену лексему mеn даље спецификовану: working in the field. Jезички систем допушта некада да се једна компонента значења пренесе и творбеним поступцима: „мезетити“ на словеначком префикасацијом постаје prigrizovali, a у енглеском слично значење се остварује конверзијом - snacking on.

Ипак, у неким случајевима, шири језички и културни контекст оригинала остао је без праве еквиваленције. Један смо већ навели: градећи три историјска 
слоја, три све удаљеније приче (поп Вујадин, Аника, Тијана) писац је употребио истоветну лексему јечерма, али су оне преведене различито иако се ради о двема истоветним, а драматичним сценама везаним за две јунакиње. Други пример се односи на сцену описану у двадесетак редова, у којој Газија, рибар, „испијао полић ракије“ што је у сва три превода пренесено као да он пије литар, боцу, или низ чаша ракије. Имерфектни глагол „испијати“ је можда утицао на такав превод, иако у српском постоји могућност употребе имперфективних глагола у перфективном значењу (Грицкат). Још битнија је чињеница да се одмах после тог глагола писац прелази на презентске облике глагола којима се отпочиње кулминација те кратке сцене: „Питиају га какав је ове године мрест и колико је уловио и продао, а он као сви ловци празноверно крије и избеїава тачан одговор“. Из преласка писца на презент, а и из целог контекста, види се да је он с ногу, стојећи, држећи мрежу која се цедила, и сл., заправо кратко био у дућану (енглески преводилац га поставља „на сред“ coffeehouse, како преводи дућан) те је заиста испијао „полић“ а не више њих. Другим речима, док се културолошки може замислити „дружење у дућанима“ у нашем поднебљу, то је, чини се, контекст који је остао неразумљив преводиоцима, па је и лексема „полић“ добила не-еквивалентна тумачења у преводима.

Можемо да закључимо да се проблем проналажења еквивалентних лексема и израза у преводу може решавати само ако се има на уму не само културни, регионални и просторни контекст, већ и шири језички, текстуални и књижевни контекст једног писца, што показује наша анализа културно-специфичних појмова и речи у српском и три анализирана превода приповетке „Аникина времена“ Ива Андрића. 
Културно-специфична лексика у преводу Ива Андрића... 259

Извори и литература

Andrić, Ivo. Pripovetke. Novi Sad: Matica srpska, Beograd: Srpska književna zadruga, 1971

Andrić, Ivo. The slave girl : and other stories about women. Gorup, R. (ed.), Martonvásár, Akadémiai Nyomda; preštampano iz Ivo Andrić, 1962. The Vizier's Elephant: Three Novellas / translated by Drenka Willen. - New York : Harcourt, Brace \& World, 2009

Andrić, Ivo. Izbrana krajsa proza. ur. Janko Motler, izabral Stanko Šimenc. Ljubljana: Cankarjeva založba, 1985. 63-132

Andritch, Ivo. Le Temps d'Anika, traduit par Anne Jelen. ed. L'Age d'Homme. Lausanne, 1979

Влахов, С. и С. Флорин. Нейревоgимое в ӥеревоgе. Москва, 1980. $47-140$.

Грицкат, И. (1957-1958). „О неким видским особеностима српскохрватског глагола“. Јужнословенски филолог̄, XX, књ. 1-4. 65-130.

Ђукановић, Маја. „Реалије у делу Ива Андрића и њихово превођење“. Научни сасиианак слависииа у Вукове gане, 22/1 (1992). 379-390

Леви, Јири. Умјейности йревођењь. Сарајево: Свјетлост, 1982.

Milutinović, Z. Introduction: „The Wisdom Effect: Ivo Andrić the Storyteller", in: I.Andric, 2009. The slave girl: and other stories about women. Gorup, R. (ed.), Martonvásár, Akadémiai Nyomda; xvii-xxxix, 2009

Munday, J. Introducing translation studies. New York: Routledge, 2001

Nida, E. and Ch. Taber. The theory and practice of translation. Leiden: Brill, 1982

Флорин, С. Реалии в йеревоgе. Преводна књижевност. Београд, 1981. 47-52

Шкаљић, А. Туриизми у срйскохрвайском језику. Сарајево: Свјетлост, 1965 
Maja Đukanović

Vesna Polovina

\title{
CULTURE SPECIFIC LEXICON IN THE TRANSLATION OF IVO ANDRIĆ IN SLOVENIAN, FRENCH AND ENGLISH
}

\begin{abstract}
Summary
Based on the analysis of Ivo Andric's novella Anikina vremena and its translations into Slovenian, French and English, we compared the original culture-specific lexemes and expressions and the type of solutions the translators have chosen in order to render that specificity. The majority of lexemes referring to administrative and proper names of places and functions have been simply taken over in the translations, often with additional footnotes and explanations (except for Slovenian). Most of the other lexemes, referring to clothes, furniture, food and drink, jobs and crafts, measures and money, religious titles and holidays, were rendered successfully, with a high degree of equivalnce, whereas the some were given in generalized terms, sometimes with additional attributes, or ommitted. Interestingly some of the commonest words (bread, master, etc.) presented a greater chalenge. Some curious and culturally unfit translations could have been avoided had the translators taken into account the linguistic, cultural and wider textual context of the original more.
\end{abstract}

